\title{
The Challenges of Tourism- With Specific Reference to Muscat Region (A Conceptual Perspective)
}

\author{
Syed Aulia \\ Research Scholar - Faculty of Management Department, Pacific Academy of Higher Education and \\ Research University, Udaipur
}

\begin{abstract}
The study is aimed to find out the key challenges of tourism in Oman with specific reference to Muscat region. It focuses and investigates the challenges which are faced in the tourism and also to understand the needs of tourists and tourist operators, and identify the gap. The results of basic conceptual research with the help of structured questionnaire will form the base of primary information, publications, print media and online sources used for secondary information and literature review to make the opinions expressed in this study more trustworthy. Descriptive research design being used in this research.
\end{abstract}

Keywords: Tourism, Tourism challenges, Tourist, Tourist operators, Muscat.

\section{INTRODUCTION}

Tourism industry is the largest industry and the highest source of economic development and income generation of many counties, Oman has been consider as the second largest country in the middle east processing wealth of natural resources to offer to the tourists. Oman is one among the most best countries of the world for tourism industry it has been shown the strengths' of tourism and the ways of improve it, weakness' and the ways of improve it, opportunities and the ways of catching it and the threats and its ways to decrease it for tourism industry.

Since Oman is moving towards on other resources rather than relying on petrol, tourism has gained special attention by government since then. However, many difficulties has fact the Sultanate in this tourism sector. Therefore, the main focus of the study is to look into the challenges and obstacles which are facing tourism in Oman trying to overcome it to achieve highest level of satisfaction for the tourists, by evaluating the current status of this sector and comparing it with the desired standard. The study will focus on the needs of tourism sector and how to manage it to help it boost the economy of the Sultanate in the long-run to compensate and support the current economy sources.

Briedenhann, J., \&Wickens, E. (2004) The statement that tourism is a highly international activity, and that employees are regularly likely to meet foreigners in jobs at all levels, are two recognizable reasons. The internationalization of firms and the cross-border impact of business standards and models add to the international imperative, containing in the educational system (Purcell, K., Quinn, J. 1995)

Barron, P. and Maxwell, G. (1993) Students' own travel experiences prior to their studies , including working out of the country are a more recent tendency that the providers of tourism education cannot flout. Tourism as practiced in developed countries, is essentially an economic endeavor, whereas in developing countries it is mainly about leisure consumption as path to development (Jenkins, 1980).

Lack of strategic alignment between the expectations and needs of tourists is a key area of concern, in view of needs mutually beneficial relationships between the challenges of tourists and services provided by tourism industry to meet these needs and reach to the high level of customer satisfaction. (Kusluvan, S., Kusluvan, Z.,2000).

\section{THEORETICAL CONCEPTS \& FRAMEWORK}

Tourists satisfaction of tourism industry is very important for the success and growth of tourism business. Apart from having good infrastructure and facilities its always important to focus on tourist (customer) satisfaction, which is utmost important and It is often referred as "A HAPPY TOURIST IS SATISFIED TOURIST". A happy tourist is generally that traveler who is satisfied with that place. 


\section{DEFINITIONS}

Satisfaction: In simple words, satisfaction can defined as extent of positive feelings or attitudes that individuals have towards their life. When a person says that he has high feeling of satisfaction, it means that he really likes his trip, feels good about it and values it.

Tourism: "The people, activities, and organizations involved in providing services for people on holiday, for example hotels, restaurants, and tour guides"

Tourist: "A person who travels to a place for pleasure"

Sustainable Tourism: "Sustainable tourism development requires the informed participation of all related stakeholders. Sustainable tourism need to maintain a high level of tourist satisfaction and ensure a meaningful experience to the tourists, raising their awareness about sustainability problems and promoting sustainable tourism practices amongst them.

Achieving sustainable tourism is a continuous process and it requires constant monitoring of impacts, introducing the necessary preventive and/or corrective measures whenever necessary (Szivas, Riley, \& Airey, 2003).

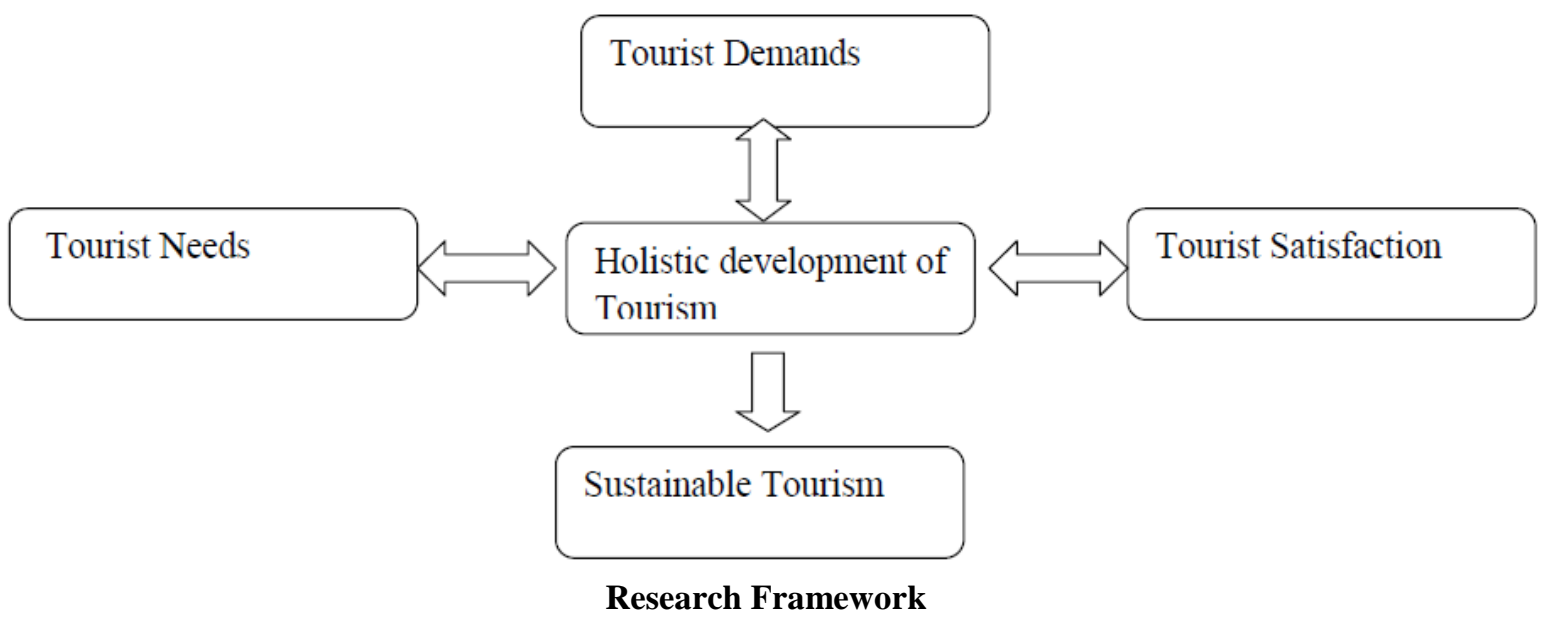

\section{SigNifiCANCE OF STUdY}

Oman being inclined to develop tourism and strengthen its economy with further economic development in Oman. The significance is to study about the tourism and views of studying the tourism from different sections about the perception of tourism from tourist point of view and also to know the gaps in infrastructure and other perspectives of tourism industry.

Moreover, the research has been done to know the significance level of tourism through questionnaire and interviews. The purpose is to now the challenges faced in the tourism sector in the Muscat region of Oman and also to understand the needs and demands of tourists. In addition, the study is trying to know the level of satisfaction of tourist's and also to highlight the situation of tourism industry in Muscat region in present scenario.

\section{Research Questions}

What are the key challenges that facing the tourism in Muscat region of Oman?

What are the main needs of tourist?

What is the relationship between tourism perception and satisfaction of tourists?

What is the current scenario of tourism in Muscat region?

\section{Research Objectives}

- To find out the key challenges faced by tourist in the Muscat region.

- To examine the perceived satisfaction of tourists.

- To evaluate the present status of tourism sector. 


\section{Scope of Study}

The scope of the research is being focused in the Muscat region of Oman. This study includes employees of tourism agencies and tourist visiting the Muscat region. The perceptions of tourists and respondents are collected using a questionnaire by focusing on key issues in tourism industry.

\section{Sample Unit}

A sample is a subset of the population. For this study survey being conducted for the employees of tourism agencies and tourist visiting the Muscat region.

\section{Data Collection}

Data was collected from both primary and secondary sources.

\section{Primary Data}

Primary data: primary data that it has been collected through different methods such as questionnaires, interviews, and observation.

\section{Secondary Data}

Secondary data: secondary data have been collected from different sources such as articles, internet, journals, and reports.

\section{Sample Size}

Out of 100 questionnaires distributed only 80 questionnaires were filled.

\section{Limitation of Study}

- Some respondents are hesitant while answering the questions.

- The findings and conclusions may not be free from biasness as data extracted from interviews and observations as well.

\section{RESUlTS AND DisCUSSIONS}

\subsection{The Key Challenges which are Faced by the Tourism in Muscat}

The tourism sector in Oman faces some of the challenges that must the government with the private sector analyze it and get a solutions to improve the tourism . The main challenges is the lack of cooperation between private sector and government sector (40\%), also many respondents believe that Oman media(55\%) does not contribute to the tourism and encourage the tourists to give information abroad the country .In addition, English language is one of the obstacles that faces the Omanis to deal with the tourists or work in this sector.Also one of challenges that the government must focus on it is the price of the hotels in Oman (32\%) compare to the other countries and the transportation issues that need to be modern and accessibility to reach locations (74\%).Also one of the important challenges that need to focus on it is the infrastructure in Oman (52\%)which need to reformatting to be modern and attractive. The respondents believe that the government need to support the tourism sector and focus on it .The private sector experiences and restrictions to deal with the tourists need to look on it as a challenges and find some solutions by cooperating with the government. Also the lack of commitment by Tourist operators in Oman discourages tourist to come in Oman is one of the challenge that need to study it and find the solutions to its.

\subsection{Understand the Needs of Tourist}

Oman has a constituent tourist as a natural factors and some of the new projects that need to be match the tourists needs .The government and private sector in Oman need to focus in finding new methods to attract tourists to come in Oman.Also the Oman media must play important role in attractive foreigners to come to Oman.The government should have a clear strategy about the tourists sector in Oman and need to re structure the tourist infrastructure to compete with other countries. Also the government should understand the challenges and set a plane to deal with all difficulties to solve the all problems .The government, private sectors and Omanis people should cooperate together to encourage this sector .In addition, the government should implement programs to improve the knowledge of people about the tourists and its benefits. 


\subsection{Examine the Perceived Satisfaction of Tourists}

Most of the respondents answer from public and private agency believe that the tourists are satisfied (60\%) about Oman and they may took this impressions from their interaction with tourists .Most of the tourists like the Ecological ,historical and natural elements and this is represent from the answers of the respondents that $(85 \%)$ believe on that .Also some of the facilities that in some locations in Oman ,Tourists find it attractive.

\subsection{Evaluate the Present Status of Tourism Sector in Muscat}

Now a day's tourism sector in Oman faces different challenges that need to look on it which has been mention above and the government has to get a strategic plane to get solutions to all challenges .Cooperation between the government and private sector is very important and this factor is not to be improved on. Also the infrastructure of tourism in Oman needs to be re structure and find new methods to attract more number of tourists.

\section{Conclusion}

Tourism has recently become one of the most important areas concerning the economy of the Sultanate of Oman. Therefore, the concern in improving this area has grown wide. My study, thus, focuses on the challenges of tourism in Oman in order to look into this important aspect in the Sultanate's economy. The study revealed that, in general, tourists are satisfied with tourism in Oman despite the gaps and problems facing this area. The government need to exert more effort and undergo more studied plans to improve tourism and make individuals aware of its importance and how to best utilize it for the good of the country's economy, be it an interior tourism or an international tourism.

\section{Suggestions}

1. The government should work more towards creating awareness about the significance of tourism among individuals, students at schools, employees, etc.

2. There should be specific syllabus for students at schools to instill the importance of tourism in the young generations.

3. There should be constant follow-up of tourist's complaint so that to improve the quality of services offered for tourists.

\section{BIBLIOGRAPHY}

Barron, P. and Maxwell, G. (1993) Hospitality management students' image of the hospitality industry. International Journal of Contemporary Hospitality Management, 5(5), 5-8.

Briedenhann, J., \&Wickens, E. (2004). Tourism routes as a tool for the economic development of rural areas-vibrant hope or impossible dream? Tourism Management, 25(1), 71-79.

Jenkins, C. L. (1980). Tourism policies in developing countries: a critique. Tourism Management, vol 1, issue1, pages22-29.

Kusluvan, S., Kusluvan, Z., (2000). Perceptions and attitudes of undergraduate tourism students towards working in the tourism industry in Turkey. Tourism Management, vol 21, pages 251269.

Purcell, K., Quinn, J. (1995), Hospitality Management Education and Employment Trajectories, School of Hotel and Catering Management, Oxford.

Szivas, Riley, \& Airey, ( 2003). Planning tourism employment: a developing country perspective, Tourism Management vol27 pages159-170.

\section{Websites}

www.arabiantravelnews.com

www.destanationoman.com

www.hoteliermiddleeast.com

www.omantourism.gov.om

www.omanworldtourism.com

www.ymagazine.com 